\title{
Komparasi Algoritma Klasifikasi Data Mining untuk Memprediksi Tingkat Kematian Dini Kanker dengan Dataset Early Death Cancer
}

\author{
Panny Agustia Rahayuningsih \\ panny.par@bsi.ac.id
}

\author{
Program Studi Sistem Akuntansi Kampus Kota Pontianak, \\ Fakultas Teknologi Informasi, Universitas Bina Sarana Informatika
}

\begin{abstract}
Cancer is something big in the world. Cancer is a malignant disease that is difficult to cure if the spread is too wide. However, detecting cancer cells as early as possible can reduce the risk of death. This study aims to predict the level of early detection of disasters in European countries using 5 classification algorithms, namely: Desecion Tree, Nä̈ve Bayes, $k$-Nearset Neighbor, Random Forest and Neural Network of which algorithm is the best for this study. Tests carried out with several stages of research include: dataset (data contains), initial data processing, proposed method, credit method using 10 times cross validation, test results and t-test different tests. The alpha value is 0.05 . if the probability is $>0.05$ then $\mathrm{HO}$ is accepted. If the probability is $<0.05$ then $\mathrm{Ho}$ is rejected. The results of the research that obtained performance with an accuracy value of $98.35 \%$ were the Neural Network algorithm. Whereas, the results of the research using the algirtic t-test with the best models are: Random Forest algorithm and Neural Network, the relatively good Nä̈ve Bayes algorithm, the Desecion Tree algorithm is quite good and the poor algorithm is the K-Nearset Neighbor (K-NN) algorithm.
\end{abstract}

Intisari- Penyakit Kanker merupak an sepuluh besar penyakit pembunuh di dunia. Kanker merupakan penyakit yang ganas dan sulit disembuhkan jika penyebarannya sudah terlalu luas. Akan tetapi, pendeteksian sel kanker sedini mungkin dapat mengurangi resiko kematian. Penelitian ini bertujuan untuk memprediksikan tingkat kematian dini kanker pada penduduk Eropa dengan menggunakan 5algoritma klasifikasi yaitu: Desecion Tree, Nä̈ve Bayes, $k$-Nearset Neighbour, Random Forest dan Neural Network dari algoritma tersebut algoritma mana yang dianggap paling baik untuk penelitian ini. Pengujian dilakukan dengan beberapa tahapan penelitian antara lain: dataset (pengumpulan data), pengol ahan data awal, metode yang diusulkan, pengujian metode menggunakan 10-fold cross validation, evaluasi hasil dan uji beda t-test. Nilai alpha yang digunak an adalah 0.05. jika probabilitasnya $>0.05$ maka $\mathrm{H}_{0}$ diterima. Sedangkan jika probabilitasnya $<0.05$ maka $\mathrm{H}_{0}$ ditolak.Hasil dari penelitian yang mendapatk an performe terbaik dengan nilai akurasi sebesar 98,35\% adalah algoritma Neural Network. Sedangkan, hasil penelitian menggunakan uji $t$-test algoritma dengan model terbaik yaitu: algoritma Random Forest dan Ne ural Network, algoritma Nä̈ve Bayes lumanyan baik, algoritma Desecion Tree cukup baik dan algoritma yang kurang baik adalah algoritma $K$-Nearset Neighbour (KNN).

Kata kunci: Kanker, Algoritma, Klasifikasi, Probability

\section{PENDAHULUAN}

Menurut catatan WHO, Kanker merupakan sepuluh besar penyakit pembunuh di dunia [1]. Kanker adalah istilah yang digunakan untuk penyakit dimana sel-sel abnormal membelah tanpa kontrol dan mampu menyerang jaringan sel lain. Sel-sel kanker dapat menyebar ke bagian lain tubuh melalui pembuluh darah dan sistem limfe [2]. Kanker bukan hanya satu penyakit tapi banyak penyakit, ada lebih dari 100 berbagai jenis penyakit kanker [1]. Jaringan yang telah diserang oleh sel-sel kanker tidak akan berfungsi normal lagi dan akhirnya berujung pada kegagalan fungsi organ yang mengakibatkan kematian [1][3].

Kanker merupakan penyakit yang ganas dan sulit disembuhkan jika penyebarannya sudah terlalu luas. Akan tetapi, pendeteksian sel kanker sedini mungkin dapat mengurangi resiko kematian [4]. Kanker adalah sekelompok penyakit yang dapat menyebabkan hampir semua tanda atau gejala. Tanda-tanda dan gejala akan tergantung pada di mana kanker, seberapa besar itu, dan berapa banyak mempengaruhi organ atau jaringan di dekatnya [5]. Jika kanker telah menyebar (metastasis), gejala dapat muncul di berbagai bagian tubuh. Penyakit kanker merupakan salah satu penyebab kematian utama di seluruh dunia. Pada tahun 2012, kanker men jadi penyebab kematian sekita 8,2 juta orang. Berdasarkan data GLOBOCAN, International Agency Of Research on Cancer (IARC) diketahui bahwa pada tahun 2012 terdapat 14.067.894 kasus baru kanker dan 8.201.575 kematian akibat kanker di seluruh dunia. Penyebab terbesar kematian akibat 
kanker setiap tahunnya antara lain disebabkan oleh kanker paru, hati, perut, kolorektal, dan kanker payudara.

Penyakit kanker kini merupakan penyakit yang paling berbahaya di Negara Eropa [4]. Di benua Eropa yang terdiri dari 53 negara, WHO menyebutkan penyakit jantung mencabut nyawa lebih dari 4 juta orang pada 2016. Jumlah kematian in i setara dengan 45 persen dari semua ke matian di negara-negara Eropa. Sementara itu kan ker bertanggung jawab atas kurang dari setengah angka kematian akibat penyakit jantung di Eropa secara keseluruhan. Kanker, seperti dipaparkan dalam European Heart Journal, kini membunuh lebih banyak lelaki daripada penyakit jantung di 12 negara Eropa ini: Belgia, Denmark, Prancis, Israel, Italia, Lu xe mbourg, Belanda, Norwegia, Portugal, Slovenia, Spanyol dan Inggris Raya.

Klasifikasi menentukan tingkat kematian dini kanker merupakan hal yang sangat penting untuk melakukan diagnosis secara dini agar dapat mengetahui mana yang lebih baik, lebih buruk dan tidak ada perubahan yang signifikan dari rata-rata [6]. Dalam proses klasifikasi terdapat banyak algoritma [7] yang digunakan untuk menentukan mana algoritma yang dianggap paling baik pada proses klasifikasi [8][9]. Penelitian ini dilakukan untuk mengetahui algoritma data mining mana yang baik dalam mengklasifikasi data Earlydeathcancer pada penduduk Eropa. Penulis membandingkan beberapa metode klasifikasi data mining,diantaranya yaitu Algoritma C4.5, Neural Network, Naives Bayes, $K-N N$ dan Random Forest. Hasil klasifikasi dari masing-masing algoritma akan dibandingkan dan dilihat tingkat akurasinya.

\section{METODE PENELITIAN}

\section{A. Penyakit Kanker}

Penyakit kanker adalah sel tubuh yang mengalami mutasi (perubahan) dan tumbuh tidak kendali serta membelah lebih cepat dibandingkan dengan sel normal. Sel kanker tidak mati setelah usianya cukup., melainkan tumbuh terus dan bersifat invasif sehingga sel normal tubuh dapat terdesak atau malah mati. Penyakit kanker adalah penyakit yang timbul akibat pertumbuhan tidak normal sel jaringan tubuh yang berubah menjadi sel kanker.

\section{B. Data Mining}

Data Mining adalah suatu disiplin ilmu yang bertujuan menemukan, menggali atau menambahkan pengetahuan dari data atau informasi yang kita miliki.

\section{Algoritma Klasifikasi Data Mining}

Klasifikasi Data Mining adalah suatu metode pembelajaran., untuk memprediksi nilai dari sekelompok attribut dalam menggambarkan dan membedakan kelas data atau konsep yang bertujuan untuk memprediksi kelas dari objek yang label kelasnya tidak diketahui.

\section{Algoritma Tree C4.5}

Algortima C4.5 merupakan bagian dari kelompok algoritma decision tree dan merupakan kategori 10 algoritma yang paling popular[9]. Algoritma C4.5 diperkenalkan oleh J.Ross Quin lan diakhir tahun 1970 hingga awal tahun 1980-an. J. Ross Quin lan seorang peneliti dibidang mesin pembelajaran yang merupakan penge mbangan dari algorit ma ID3 (Interative Dichotomiser), algoritma tersebut digunakan untuk membentuk pohon keputusan. Pohon keputusan dianggap sebagai salah satu pendekatan yang paling popular, dalam klasifikasi pohon keputusan terdiri dari sebuah node yang membentuk akar node akar tidak memiliki inputan. Node lain yang bukan sebagai akar tetapi memiliki tepat satu inputan disebut node lainnya dinamakan daun. Daun mewakili nilai target yang paling tepat dari salah satu class.

Konsep dari algorit ma $\mathrm{C} 4.5$ adalah mengubah data menjadi pohon keputusan dan aturan-aturan keputusan (rule). C4.5 adalah algoritma yang cocok untuk masalah klasifikasi dan data mining. Memetakan nilai atribut menjadi class yang dapat diterapkan untuk klasifikasi baru. Tahapan dalam membangun sebuah pohon keputusan dengan algoritma C4.5, yaitu:

1. Menyiapkan data training. Data training biasanya diambil dari data histori yang pernah terjadi sebelumnya dan sudah dikelompokkan ke dalam kelas-kelas tertentu.

2. Menentukan akar dari pohon. Akar akan diambil dari atribut yang dipilih, dengan cara mengitung nilai gain dari masing-masing atribut.,nilai gain yang paling tinggi yang akan menjadi akar pertama. Sebelum menghitung nilai gain dari atribut, hitung dahulu nilai entropy. Untuk menghitung nilai entropy digunakan rumus.

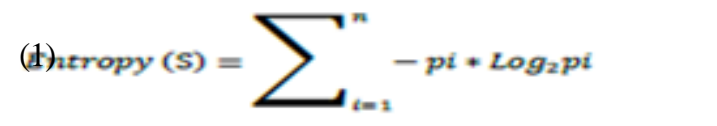

Keterangan:

$\mathrm{S}:$ himpunan kasus

A : atribut

$\mathrm{N}$ : Jumlah partisi $\mathrm{S}$

$\mathrm{Pi}$ : proporsidari Si terhadap $\mathrm{S}$

3. Kemudian hitung mulai gain yang menggunakan rumus:

$$
\operatorname{Gain}(S, A)=\operatorname{Entropy}(S)-\sum_{i=1}^{n} \frac{|s i|}{|s|} * \operatorname{Entropy}(s i)
$$

Keterangan :

$\mathrm{S}:$ himpunan kasus

A : fitur

$\mathrm{n}$ : jumlah partisi atribut $\mathrm{A}$

$|\mathrm{Si}|$ : proporsiSi terhdapa $\mathrm{S}$

$|\mathrm{S}|$ : jumlah kasus dalam $S$

4. Ulangi langkah ke-2 hingga semua record terpartisi.

5. Proses partisi pohon keputusan akan berhenti saat: 
a. Semua record dalam simpul $\mathrm{N}$ mendapat kelas yang sama.

b. Tidak ada atribut di dalam record yang dipartisi lagi.

c. Tidak ada record di dalam cabang yang kosong.

\section{E. Neural Network}

Neural Network adalah satu set unit input/output yang terhubung dimana tiap relasinya memiliki bobot, selama fase pembelajaran, neural network menyesuaikan bobot sehingga dapat memprediksikan class yang benar dari tupple. Neural Network dimaksudkan untuk mensimulasikan perilaku sistem biologi susunan syaraf manusia, yang terd iri dari sejumlah besar unit pemroses. Neuron mempunyai relasi dengan synapse yang mengelilingi neuron-neuron lainnya. Susunan sayaraf tersebut dipresentasikan dalam neural network berupa graf yang terdiri dari simpul (neuron) yang dihubungkan dengan busur, yang berkorespondensi dengan synapse. Sejak tahun 1950-an, neural network telah digunakan untuk tujuan prediksi, bukan hanya klasifikasi tapi juga regresi dengan atribut target continu.

Langkah pembelajaran algoritma backpropagation adalah sebagaiberikut:

1. Inisialis asikan bobot jaringan secara acak (biasanya antara$1.0 \mathrm{~s} / \mathrm{d} 1.0)$

2. Untuk setiap data pada data training, hitung input untuk simpul berdasarkan nilai input dan bobot jaringan saat itu. Dengan menggunakan rumus:

$$
\operatorname{Input}_{j}=\sum_{i=1}^{n} O i w_{i j}+\square_{j}
$$

Keterangan:

$\mathrm{O}_{\mathrm{i}}=$ output simpul I dari layer sebelumnya.

$\mathrm{W}_{\mathrm{ij}}=$ bobot relasidari simpul I pada layer sebelumnya ke simpul $\mathrm{j}$.

$\square_{\mathrm{j}}=$ bias (sebagai pembatas)

3. Berdasarkan input dari langkah kedua, selanjutnya membangkitkan output untuk simpul menggunakan fungsi aktifitas sigmoid:

$$
\text { ouput }=\frac{1}{1+c^{- \text {inpue }}}
$$

4. Hitung nilai error antara nilai yang diprediksi dengan nilai yang sesungguhnya menggunakan rumus:

$$
\begin{array}{r}
\text { Error }_{j}=\text { ouput }_{j} *\left(1-\text { Output }_{j}\right) \\
\text { Output } \\
\text { Ourget }
\end{array}
$$

Keterangan:

Output $_{j}=$ Output actual dari simpul j
Target $_{\mathrm{j}}=$ nilai target yang sudah diketahui pada data training.

5. Setelah nilai error dihitung, selanjutnya dibalik ke layer sebelumnya (backpropagatioan). Untuk menghitung nilai error pada hidden layer, menggunakan rumus:

ErrorJ =

ouput $_{j} *\left(1-\right.$ ouput $\left._{j}\right) * \sum_{k=1}^{n}$ errork $w_{j k}$

Keterangan:

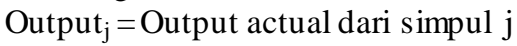

Error $_{\mathrm{j}}=$ Error dari simpul $\mathrm{k}$

$\mathrm{W}_{\mathrm{jk}}=$ Bobot relasi dari simpul $\mathrm{j}$ ke simpul $\mathrm{k}$ pada layer berikutnya.

6. Nilai error yang dihasilkan dari langkah sebelumnya digunakan untuk memperbarui bobot relasi, dengan menggunakan rumus:

$$
W_{i j}=W_{i j}+\mathrm{i} * \text { Error }_{j} * \text { Output }_{i}
$$

Keterangan:

$\mathrm{W}_{\mathrm{ij}}=$ bobot relasi dari unit i pada layer sebelu mnya ke un it $\mathrm{j}$.

$l=$ learning rate (konstantan, nilainya 0 sampai dengan 1$)$

Error $=$ Error pada output layer simpul $\mathrm{j}$

Output $=$ Output dari simpul i.

\section{F. Naive Bayes}

Nä̈ve Bayes merupakan metode yang tidak memiliki aturan. Nä̈ve Bayes menggunakan cabang matematika yang dikenal dengan teori probabilitas untuk mencari peluang terbesar dari kemungkinan klasifikasi, dengan cara melihat frekuensi tiap klasifikasi pada data training. Nä̈ve Bayes merupakan metode klasifikasi popular dan masuk dalam sepuluh algorit ma terbaik dalam data mining. Bentuk u mum dari teorema bayes dapat dilihat pada persamaan berikut:

$$
P(H \mid X) \frac{P(H \mid X) P(H)}{P(X)}
$$

Dimana:

$X$ : Data dengan class yang belum diketahui.

$\mathrm{H}$ : Hipotes is data $\mathrm{X}$ merupakan suatu class spesifik

$\mathrm{P}(\mathrm{H} \mid \mathrm{X})$ : Probabilitas hipotesis $\mathrm{H}$ berdasarkan kondisi $\mathrm{X}$ (posterior probability)

$\mathrm{P}(\mathrm{H})$ : Probabilitas hipotesis $\mathrm{H}$ (prior probability)

$\mathrm{P}(\mathrm{X} \mid \mathrm{H})$ : Probabilitas $\mathrm{X}$ berdasarkan kondisi pada hipotes is $\mathrm{H}$

$\mathrm{P}(\mathrm{X})$ : Probabilitas dari $\mathrm{X}$

\section{G. K-Nearest Neighbour}

Algoritma K-Nearest Neighbour adalah suatu metode yang menggunakan algoritma supervised. Tujuan dari algoritma $K$ - 
Nearest Neighbour adalah untuk mengklasifikasi objek baru berdasarkan atribut dan training samples. Pada proses klasifikasi algoritma ini tidak menggunakan model apapun untuk dicocokkan dan hanya berdasarkan pada memori algoritma K-Nearest Neighbour menggunakan klasifikasi ketetanggaan sebagainilai prediksi dari sampel uji yang baru.

Euclidean Distance

$$
d(x, y)=\sqrt{\sum_{k=1}^{n}\left(X_{k}-Y_{k}\right)^{2}}
$$

Manhattan Distance

$$
(x, y)=\sqrt{\sum_{k=1}^{n}\left|X_{k}-Y_{k}\right|}
$$

Untuk mengukur jarak dari atribut yang mempunyai nilai besar, seperti atribut pendapatan, maka dilakukan normalisasi. Normalisasi bisa dilakukan dengan min-max normalization atau Z-score standardization. Jika data training terdiri dari atribut campuran antara numerik dan kategori, lebih baik gunakan min-max normalization .

$$
\begin{aligned}
x^{*} & =\frac{x-\min (x)}{\max (x)-\min (x)} \\
x^{*} & =\text { Standarisasi min-max }
\end{aligned}
$$

Dimana:

Min $(\mathrm{x})=$ Nilai minimum data sampel

Max (x) =Nilai maximum data sampel

\section{H. Random Forest}

Random forest adalah algoritma klasifikasi den regresi yang merupakan bagian dari kelompok ensemble learning. Model base classifier yang dipakai adalah decision tree sehingga membentuk 'forest' atau hutan. Random forest dipopulerkan oleh Leo Breiman.

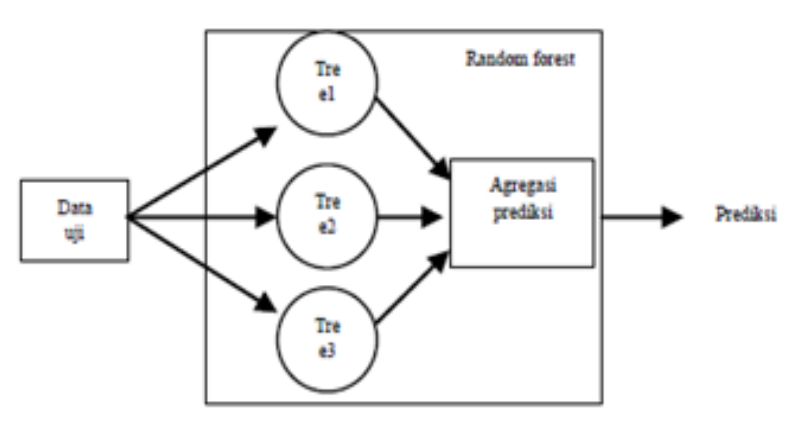

Gambar 1 Proses Prediksi Random Forest

Dalam random forest, pemilihan atribut dalam setiap kali sebuah node akan dipecah diambil secara acak,. Pertama-tama setiap tree diberi sample data training dengan menggunakan metode bagging, dan tiap tree dibangun menggunakan metode yang sama untuk membangun CART. Perbedaan yang mencolok terdapat pada proses pemilihan splitting criterion.
Alih-alih mempertimbangkan seluruh atribut yang ada pada data, random forest hanya mempertimbangkan subset dari keseluruhan atribut (biasanya jumlah atribut yang diseleksi ditentukan oleh user). Atribut yang akan diseleksi ini didapatkan secara acak. Seperti CART, pembangunan tree akan berhenti ketika data sudah homogeny atau batas jumlah data minimum terlewati. Namun terdapat variasi Random Forest yang menentukan besar kedalaman tree maksimum.

Random Forest dapat menangani data dengan dimensi tinggi dengan baik dibanding model classifier lainnya. Berbeda dengan Decision Tree biasa, overfitting diatasi dengan menjaga variansi model tree dalam forest. Dalam Random u mumnya tidak terdapat leaf pruning (penghilangan node leaf), tetapi variasi Random Forest seperti Hough Forest dalam implementasinya menerapakan leaf pruning untuk menghilangkan leaf node dengan probabilitas rendah.

Random Forest juga memiliki nama Decission Tree dalam pengaplikasiannya memiliki beberapa variasi, anatar lain Extremely Randomized Tree, dan Hough Forest. Random Forest dapat melakukan klasifikasi, regresi dan bahkan clustering. Hal ini menjadi daya tarik random forest dan turut mendorong aplikasi dan penelitian random forest dalam bidang computer vision.

\section{Tahap Penelitian}

Dalam penelitian ini penulis menggunakan sebuah software yaitu rapid miner. Penelitian ini bertujuan melakukan perbandingan untuk menentukan algoritma mana yang memiliki akurasi paling baik dengan menggunakan dataset Early Death Cancer. Pada penelitian ini dilakukan beberapa langkah-langkah atau tahapan penelitian antara lain: dataset (pengumpulan data), pengolahan data awal, metode yang diusulkan, pengujian metode, evaluasi hasil dan uji beda t-test.

\section{J. Dataset}

Penelitian ini, penulis menggunakan dataset dari Public Health England, Health Profile Datasheets 2013. Penulis peroleh data tersebut dari http://www.apho.o rg.uk/resource/ browse.aspx? RID=126684. Public Health England merupakan suatu lembaga yang yang bergerak dibidang kesehatan. PHE adalah lembaga eksekutif, yang disponsori oleh Departemen kesehatan. Tujuannya untuk melindungi dan meningkatkan kesehatan dan kesejahteraan bangsa, dan mengurangi kesenjangan kesehatan. Dataset yang digunakan adalah Early Death Cancer. Pada dataset early death cancer terdapat 7 atribut dan 1 class seperti pada tabel 1 dibawah ini.

Tabel 1: Atribut Dataset Early Death Cancer

\begin{tabular}{|l|l|l|}
\hline No & Nama Atribut & Keterangan \\
\hline 1 & Period & 2009-2011 \\
\hline 2 & $\begin{array}{l}\text { Aggregate } \\
\text { Numerator }\end{array}$ & $\begin{array}{l}\text { Jumlah kematian akibat kanker } \\
\text { yang terdaftar pada tahun 2009, } \\
2010,2011, \text { orang yang berusia } \\
<75\end{array}$ \\
\hline 3 & $\begin{array}{l}\text { Aggregate } \\
\text { Denominator }\end{array}$ & $\begin{array}{l}\text { Jumlah dari 2011 penduduk } \\
\text { pertengahan tahun berdasarkan }\end{array}$ \\
\hline
\end{tabular}




\begin{tabular}{|l|l|l|}
\hline & & $\begin{array}{l}\text { Sensus memperkirakan 2009, } \\
2010, \text { 2011, orang yang berusia } \\
<75\end{array}$ \\
\hline 4 & $\begin{array}{l}\text { Single Year } \\
\text { Numerator }\end{array}$ & $\begin{array}{l}\text { Rata-rata jumlah tahunan } \\
\text { kematian akibat kanker, 2009- } \\
\text { 2011, orang berusia <75 }\end{array}$ \\
\hline 5 & $\begin{array}{l}\text { Single Year } \\
\text { Denominato }\end{array}$ & $\begin{array}{l}\text { Rata-rata pendudukpertengahan } \\
\text { tahun berdasarkan 2011 Sensus } \\
\text { tahunan memperkirakan 2009- } \\
\text { 2011, orang berusia <75 }\end{array}$ \\
\hline 6 & Indicator Value & $\begin{array}{l}\text { Angka kematian dini (DSR) dari } \\
\text { semua kanker (orang yang } \\
\text { berusia <75) }\end{array}$ \\
\hline 7 & 95\% CI & $\begin{array}{l}\text { Lebih rendah 95\% CI dan Atas } \\
\text { 95\% CI }\end{array}$ \\
\hline 8 & $\begin{array}{l}\text { Significance } \\
\text { (Class) }\end{array}$ & $\begin{array}{l}\text { Menunjukkan jika suatu daerah } \\
\text { secara signifikan lebih baik, } \\
\text { buruk atau tidak berbeda secara } \\
\text { signifikan dari rata-rata Inggris, } \\
\text { berdasarkan apakah nilai rata- } \\
\text { rata Inggris termasuk dalam } \\
\text { 95\% }\end{array}$ \\
\hline
\end{tabular}

\section{K. Pengolahan Awal Data}

Jumlah data yang digunakan adalah 363 data. Untuk mendapatkan data yang berkualitas, beberapa teknik yang dilakukan adalah sebagaiberikut.

1. Data validation, untuk mengidentifikasi dan menghapus data yang ganjil (outlier/noise), data yang tidak konsisten, dan data yang tidak lengkap (missing value).

2. Data integration and Transformation, untuk meningkatkan akurasi dan efisiensi algoritma. Data ditransformasikan ke dalam software RapidMiner.

3. Data size reduction and dicrtization, untuk memperoleh data set dengan jumlah atribut dan record yang lebih sedikit tetapi bersifat informatif.

\section{Metode dan Evaluasi}

Dalam penelitian ini adapun metode dan evaluasi yang akan dilakukan dengan menggunakan metode eksperimen yaitu menggunakan beberapa metode klasifikasi data mining terhadap dataset Earlideathcancer yang dimana untuk menentukan tingkat kematian dini kanker pada penduduk Eropa. Data akan diolah dengan menggunakan algoritma Decision Tree, Nä̈ve Baye, K-NN, Random Forest, Neural Network dan menghasilkan model, maka terhadap model yang dihasilkan tersebut dilakukan pengujian menggunakankan $k$ fold cross validation, kemudian dilakukan evaluasi dan validasi hasil dengan confusion matrix dan uji beda t-test

\section{Pengujian Model}

Pengujian model dalam penelitian in i menggunakan Cross Validation adalah teknik validasi dengan me mbagi data secara acak kedalam $\mathrm{k}$ bagian dan masing-masing bagian akan dilakukan proses klasifikasi.

Cross Validation akan dilakukan sebanyak 10 kali untuk memperkirakan akurasinya. Pada penelitian ini, nilai $\mathrm{k}$ berju mlah 10 atau 10-fold cross validation. Berikut contoh 10fold cross validation pada tabel 2 sebagaiberikut:

Tabel 2: 10-Fold Cross Validation

\begin{tabular}{|c|c|c|c|c|c|c|c|c|c|c|}
\hline n-Validasi & \multicolumn{2}{|l|}{ Dataset } \\
\hline $\mathbf{1}$ & & & & & & & & & & \\
\hline $\mathbf{2}$ & & & & & & & & & & \\
\hline $\mathbf{3}$ & & & & & & & & & & \\
\hline $\mathbf{4}$ & & & & & & & & & & \\
\hline $\mathbf{5}$ & & & & & & & & & & \\
\hline $\mathbf{6}$ & & & & & & & & & & \\
\hline $\mathbf{7}$ & & & & & & & & & & \\
\hline $\mathbf{8}$ & & & & & & & & & & \\
\hline $\mathbf{9}$ & & & & & & & & & & \\
\hline $\mathbf{1 0}$ & & & & & & & & & & \\
\hline
\end{tabular}

\section{N. Evaluasi Hasil}

Pada penelitian algoritma klasifikasi data mining terdapat evaluasi untuk mengetahui tingkat akurasi dari algoritma klasifikasi tersebut. Dalam algoritma klasifikasi dibagi menjadi 2 data pada umunya yaitu data training dan data testing. Data training digunakan untuk membuat suatu pola dalam me mbentuk sebuah model klasifikasi. Sedangkan, data testing digunakan untuk mengukur akurasi dari algoritma klasifikasi apakah berhasil melakukan klasifikasi dengan benar.

Evaluasi menggunakan Confusion matrix untuk memberikan keputusan yang diperoleh dalam training dan testing. Confusion matrix, memberikan penilaian performace klasifikasi berdasarkan objek dengan benar atau salah. Untuk mendapatkan hasil akurasi yang lebih baik maka dilakukan percobaan. Dari percobaan yang dilakukan dalam penelitian ini adalah menghitung nilai rata-rata keseluruhan.

\section{O. Uji Beda T-Test}

Selain menggunakan Confusion matrix, pada penelitian ini juga mencoba melakukan pengujian dengan menggunakan metode uji T-Test untuk mendapatkan model terbaik. T-Test adalah metode pengujian untuk menentukan dua sampel yang tidak berhubungan yang memiliki nilai rata-rata berbeda. Caranya dengan membandingkan perbedaan dari ke dua sampel ters ebut.

\section{HASIL DAN PEMBAHASAN}

Dari hasil penelitian dengan menggunakan alat bantu rapid miner ini menunjukan algritma Neural Network dengan performa terbaik yang mendapat nilai akurasi sebesar $98.35 \%$. Algoritma Random Forest dengan nilai sebesar akurasi $96.42 \%$, algoritma Naïve Bayes dengan nilai sebesar akurasi 86.23\%. algorit ma C4.5 dengan nilai akurasi sebesar $69.97 \%$. 
sedangkan untuk algoritma K-NN mendapatkan nilai akurasi sebesar $43.80 \%$. Nilai akurasi tersebut didapat dengan menggunakan data Early DeathCancer. Keseluruhan hasil dari penelitian ini dapat dilihat pada tabel III untuk melihat hasil perbandingan akurasi pada masing-masing algoritma.

Tabel 3: Hasil Nilai Akurasi

\begin{tabular}{|l|c|}
\hline \multicolumn{1}{|c|}{ Metode } & Akurasi \\
\hline C4.5 & $69,97 \%$ \\
\hline Naive Bayes & $86,23 \%$ \\
\hline K-NN & $43,80 \%$ \\
\hline Random Forest & $96,42 \%$ \\
\hline Neural Network & $98,35 \%$ \\
\hline
\end{tabular}

Setelah mendapatkan nilai akurasi dari 5 algortima tersebut, penelitian selanjutnya adalah melakukan pengujian dengan uji beda t-test. Pada pengujian ini, uji t-test beda memiliki nilai signifikan yang berbeda pada setiap algoritmanya. Nilai alpha yang digunakan adalah 0.05 . jika probabilitasnya $>0.05$ maka $\mathrm{H}_{0}$ diterima (tidak ada perbedaan yang signifikan) sedangkan jika probabilitasnya $<0.05$ maka $\mathrm{H}_{\mathrm{o}}$ ditolak (ada perbedaan yang signifikan). Berikut ini tabel dari hasil uji T-test dari keseluruhan algoritma klasifikasi.

Tabel 4: Hasil Uji T-Test

\begin{tabular}{|c|c|c|c|c|c|}
\hline & $\mathbf{C 4 . 5}$ & $\begin{array}{c}\text { Naïve } \\
\text { Baye } \\
\mathbf{s}\end{array}$ & $\begin{array}{c}\text { K- } \\
\text { NN }\end{array}$ & $\begin{array}{c}\text { Random } \\
\text { Forest }\end{array}$ & $\begin{array}{c}\text { Neural } \\
\text { Networ } \\
\mathbf{k}\end{array}$ \\
\hline C4.5 & - & 0.022 & 0.001 & 0.000 & 0.000 \\
\hline $\begin{array}{c}\text { Naïve } \\
\text { Bayes }\end{array}$ & - & - & 0.000 & 0.001 & 0.000 \\
\hline K-NN & - & - & - & 0.000 & 0.000 \\
\hline $\begin{array}{c}\text { Random } \\
\text { Forest }\end{array}$ & - & - & - & - & 0.189 \\
\hline $\begin{array}{c}\text { Neural } \\
\text { Network }\end{array}$ & - & - & - & - & - \\
\hline
\end{tabular}

Dari tabel diatas, algortima yang lebih kecil dari nilai alpa 0.05 menunjukkan adanya perbedaan yang signifikan yaitu: algoritma C4.5 dengan Naïve Bayes, K-NN, Random Forest dan Neural Network. Algortima Naïve Bayes dengan K-NN, Random Forest dan Neural Network. Kemudian, algoritma KNN dengan Random Forest dan Neural Network. Sedangkan untuk algoritma Random Forest dengan Neural Network menunjukkan hasil lebih dari nilai alpa sehingga tidak ada perbedaan yang singnifikan. Jadi, model terbaik untuk dataset Early Death Cancer ini yaitu: algoritma Random Forest dan Neural Network.

\section{KESIMPULAN DAN SARAN}

Dari hasil penelitian yang telah dilakukan dengan menggunakan dataset EarlyDeathCancer dapat disimpulkan bahwa penelitian menggunakan 5 algoritma yaitu: decision tree, naïve bayes, k-nn, random forest, dan neural network. Pengujian dilakukan dengan menggunakan dataset dari Public Health England, Health Profile Datasheets 2013 yaitu dataset EarlyDeathCancer. Tahapan peneltian antara lain: dataset (pengumpulan data), pengolahan data awal, metode yang diusulkan, pengujian metode (10-fold cross validatio), evaluasi hasil menggunakan Confusion matrix dan uji beda ttest.

Hasil penelitian dari pengujian metode menggunakan Confusion matrix menghasilkan performe terbaik dengan nilai akurasi sebesar 98,35\% adalah algortima Neural Network. Urutan algoritma yang dihasilkan pada pengujian menggunakan uji beda t-test mendapatkan hasil model algoritma yang terbaik adalah Random Forest dan Neural Network, algoritma Naïve Bayes lumanyan baik, algoritma C4.5 cukup baik sedangkan untuk algorit ma K-NN algoritma yang kurang baik digunakan pada dataset ini.

\section{DAFTAR PUSTAKA}

[1] S. Handayani, "FAKTOR - FAKTOR YANG MEMPENGARUHI PERILAKU PEMERIKSAAN DETEKSI DINI KANKER," vol. 9, p. 33, 2010.

[2] R. R. Ananda, S. Ermayanti, and Abdiana, "Hubungan Staging Kanker Paru dengan Skala Nyeri pada Pasien Kanker Paru yang Dirawat di Bagian Paru RSUP DR M Djamil Padang," vol. 7, no. 3, pp. 430-435, 2018.

[3] A. D. Kristanto and Y. F. La Kahija, "Pengalaman Coping Terhadap Diagnosis Kanker Pada Penderita Usia Kerja Di Rumah Sakit Margono Soekarjo Purwokerto," vol. 6, no. 2, pp. 1-9, 2017.

[4] W. Astuti and A. Adiwijaya, "Principal Component Analysis Sebagai Ekstraksi Fitur Data Microarray Untuk Deteksi Kanker Berbasis Linear Discriminant Analysis," J. Media Inform. Budidarma, vol. 3, no. 2, pp. 72-77, 2019.

[5] G. Wibisono et al., "FAKTOR-FAKTOR PENENTU GEJALA PENYAKIT KANKER PAYUDARA DENGAN PENDEKATAN JARINGAN SARAF TIRUAN," vol. 1, no. 1, pp. 1-6, 2019.

[6] Sukmayenti and N. Sari, "ANALISIS DETERMINAN KANKER PADA WANITA DI RSUP DR. M. DJAMIL PADANG TAHUN 2018," vol. 0, no. 1, pp. 77-86, 2019.

[7] A. Y. Rahman and S. Sumpeno, "Segmentasi Arca pada Museum Mpu Tantular Sidoarjo Menggunakan Learning Vector Quantization,” no. December, pp. 16-21, 2016.

[8] N. Puspitasari, Y. A. Adi, and R. S. W inanda, "KESTABILAN LOKAL PADA MODEL ALGORITMA KANKER SERVIKS AKIBAT HUMAN PAPILLOMAVIRUS (HPV),” pp. 23-29, 2016.

[9] A. Y. Rahman, S. Sumpeno, and M. H. Purno mo, "Video minor stroke extraction using learning vector quantization,” no. July 2018, 2017. 